\title{
Uranine as a Tracer in the Oil and Gas Industry: Determination in Formation Waters with High-Performance Liquid Chromatography
}

\author{
Anna Król (1), Monika Gajec *(i) and Ewa Kukulska-Zając
}

Citation: Król, A.; Gajec, M.; Kukulska-Zajac, E. Uranine as a Tracer in the Oil and Gas Industry: Determination in Formation Waters with High-Performance Liquid Chromatography. Water 2021, 13, 3082. https://doi.org/ 10.3390/w13213082

Academic Editor: Maurizio Barbieri

Received: 1 October 2021

Accepted: 30 October 2021

Published: 2 November 2021

Publisher's Note: MDPI stays neutral with regard to jurisdictional claims in published maps and institutional affiliations.

Copyright: (c) 2021 by the authors. Licensee MDPI, Basel, Switzerland. This article is an open access article distributed under the terms and conditions of the Creative Commons Attribution (CC BY) license (https:/ / creativecommons.org/licenses/by/ $4.0 /)$.
Oil and Gas Institute-National Research Institute, ul. Lubicz 25a, 31-503 Kraków, Poland; krola@inig.pl (A.K.); kukulska@inig.pl (E.K.-Z.)

* Correspondence: gajec@inig.pl

\begin{abstract}
In the oil and gas industry, tracers are used to estimate residual oil saturation, to indicate the location and orientation of fractures in tight reservoirs, to identify and mark the direction of fluid flow in fractured deposits, to locate faults and discontinuities, and to measure fluid movement in injection wells during drilling. The tracers should behave in a mechanically similar manner to the tested substance, e.g., formation waters, oil or gas, and, on the other hand, they should significantly differ from them in terms of chemical properties so that it is possible to identify them. One of the fluorescent tracers used in the oil and gas industry, e.g., for inter-well tests during secondary or tertiary production methods (especially during reservoir hydration), is uranine. In order to assess the effectiveness of fluid movement measurements, it is necessary to determine the uranine content in formation waters. In this study, a method was developed to determine uranine in formation water samples using high-performance liquid chromatography with fluorescence detection (HPLC/FLD). The initial step in preparing samples for chromatographic analysis would be solid phase extraction (SPE). The method was validated and allows for the determination of uranine in formation water samples in the concentration range from 0.030 to $2.80 \mu \mathrm{g} / \mathrm{L}$. The validation of the method included the analysis of factors influencing the measurement result (sources of uncertainty), determination of the linearity range of the standard curve, determination of the quantification limit of the method, and verification of the reproducibility, selectivity, stability and correctness achieved. The method developed within the study can be successfully applied in the case of the determination of uranine content in formation water samples from the oil and gas mining industry, which are often unstable and characterized by a relatively complex matrix. After validation, the method will also be applicable to the determination of uranine in matrices with a similar physicochemical composition, e.g., to assess groundwater flow in deformed carbonate aquifers or to characterize faults that act as barriers to horizontal groundwater flow.
\end{abstract}

Keywords: uranine; tracer; high-performance liquid chromatography; HPLC/FLD; solid phase extraction; formation water

\section{Introduction}

The development of modern technologies used in industry as well as the growth in the number of transport pipelines for liquid and gaseous media has resulted in an increase in the number of potential entry points for environmentally hazardous substances. Therefore, there is a great need for inspection methods with which existing small leaks can be detected and located. Tracers can be a fast and highly sensitive way of detecting leaks. They are substances that are used to identify a process and gain information related to its nature. They should behave in a similar way to the substance being tested, e.g., formation water, gas or oil, but, at the same time, have different chemical properties in order to be identified. Meeting both requirements at the same time is a challenge [1,2]. 
In the context of the oil and gas industry, tracer methods are used for the estimation of residual oil saturation, the identification of the location and orientation of fractures in reservoirs, and the identification and determination of the fluid flow direction as well as the locations of faults and reservoir discontinuities [3,4]. The most common parameters determined by indicator methods include the velocity of fluid movement, the active pore volume, the volume fraction of phases in a porous medium, the degree of phase saturation in a porous medium, flow geometry, pore distribution geometry, and the effectiveness of wellbore zone purification [1,5]. Conducting tracer tests provides a better understanding of the oil reservoirs under study (including internal connections, inter-layer connections, and heterogeneity) [1,6]. As far as the use of tracer methods in oil and gas extraction is concerned, oil companies started to use tracers as early as in the 1960s and tracers that were already successfully used in hydrology were selected for studies [2]. Although there are several methods for obtaining accurate information for reservoir characterization, such as determining formation fluid rates and $4 \mathrm{D}$ seismic and pressure tests, tracers have proven to be a very useful and powerful tool for conducting studies in complex reservoirs for which it is very difficult to obtain data using other exploration techniques. With the development of chemicals in the 1990s, the study of water-specific tracers has become increasingly important to the petroleum industry. They are increasingly being used in the design of improved oil-recovery methods and in the tracking of flow through the reservoir, and the results obtained from testing and analysis allow the selection of the most suitable wells for the application of improved oil-recovery methods $[7,8]$.

One of the frequently used tracers in the oil and gas mining industry is uranine, or fluorescein sodium. It is a strongly fluorescent xanthene dye with the empirical formula $\mathrm{Na}_{2}\left[\mathrm{C}_{2} \mathrm{OH}_{12} \mathrm{O}_{5}\right]$ and CAS (Chemical Abstracts Service Registry Number) 518-47-8. The sodium salt of fluorescein is well soluble in water [9].

Uranine is used in hydrology to locate leaks, to check for leaks and determine water flow routes, and to assess the impact of landfills on soil and groundwater quality. It is also used in industry, diagnostics, medical and biochemical research [9-11]. The fundamental problems encountered in the use of uranine are its instability and decomposition under the influence of heat, salinity, and the $\mathrm{pH}$ and composition of the solution in which it occurs. The form of uranine occurrence depends strictly on the $\mathrm{pH}$ of the solution. For $\mathrm{pH}$ below 2, uranine in the cationic form is predominant, in the $\mathrm{pH}$ range from 2 to 5 the neutral form predominates, while in solutions with a $\mathrm{pH}$ above 5 the anionic form is most commonly found [12].

In oil and gas mining, uranine has found application in inter-well testing using secondary or tertiary extraction methods (especially during reservoir irrigation). For this purpose, it is necessary to determine the uranine content in formation waters. Formation waters extracted together with crude oil and natural gas, due to their quantity and chemical composition, are a problem for oil companies exploiting hydrocarbon deposits. On average, the world produces 2 to 3 times more water than oil. The amount of extracted water increases with the time of exploitation of the deposits, and in the case of deposits at the final stage of bailing, the amount of exploited water is 5 to 8 times greater than that of crude oil. Mostly, it is water that cannot, for example, be discharged into surface waters or used directly, because it contains not only high contents of mineral substances (water mineralization may exceed $300 \mathrm{~g} / \mathrm{L}$ ), but also other components including organic substances, gases or bacteria [1,13-18].

Currently, instrumental methods-filter fluorimeters, spectrofluorimeters, spectrometers and special $\mathrm{Ar} / \mathrm{Kr}$ lasers-as well as chromatographic methods are used to detect and determine concentrations of fluorescent tracers, including uranine [9,13,14,19-23]. The detection of uranine can be effective even at very low concentrations. Weidner et al. [24] detected uranine in mine water at the level of $3 \mathrm{ng} / \mathrm{L}=3$ BGL. When it is necessary to determine very low concentrations of analytes in the sample or in samples requiring preliminary purification and concentration, it is recommended to use chromatographic methods, which are more specific than spectrophotometric methods. 
However, the use of chromatographic methods is connected with the necessity of sample pretreatment (consisting of sample concentration and purification, e.g., by solid phase extraction-SPE) $[9,20-23,25,26]$.

Information is available in the literature on chromatographic methods for the determination of uranine in water and saline water samples. One of them is high-performance liquid chromatography (HPLC) with fluorescence detection (FLD). Fluorescence detectors (FLD) or diode array detectors (DAD) are recommended for detection, while the separation is usually performed on C-18 packed columns. Different mobile phases are also used (observed differences in composition, gradient, and flow rate) $[9,15,22,23,25]$. A summary of the uranine determination conditions described in the literature is presented in Table 1.

Table 1. Summary of data available in the literature on HPLC systems used for uranine separation in water samples.

\begin{tabular}{|c|c|c|c|c|c|c|}
\hline \multirow{2}{*}{$\begin{array}{l}\text { Column/Dimensions/Column } \\
\text { Temperature }\end{array}$} & \multirow{2}{*}{ Detector } & \multirow{2}{*}{$\begin{array}{l}\text { Excitation/Emission } \\
\text { Wavelength, } \mathrm{nm}\end{array}$} & \multicolumn{2}{|l|}{ Mobile Phase } & \multirow{2}{*}{$\begin{array}{l}\text { Uranine } \\
\text { Retention } \\
\text { Time, min }\end{array}$} & \multirow{2}{*}{ References } \\
\hline & & & Phase A & Phase B & & \\
\hline $\begin{array}{l}\mathrm{RP} 18(5 \mu \mathrm{m}) / \text { no data } \\
\text { available } / 35^{\circ} \mathrm{C}\end{array}$ & FLD & no data available & water & $\begin{array}{l}0.005 \mathrm{M} \\
\text { tetrabutylam- } \\
\text { monium } \\
\text { hydroxide in } \\
\text { methanol, pH = } \\
7.0 \text { in gradient }\end{array}$ & $\begin{array}{l}\text { no data } \\
\text { available }\end{array}$ & [22] \\
\hline $\begin{array}{l}\mathrm{RP}-18(5 \mu \mathrm{m}) / \\
4 \mathrm{~mm} \times 125 \mathrm{~mm} / 35^{\circ} \mathrm{C}\end{array}$ & FLD & $476 / 515$ & $\mathrm{ACN}$ & $\begin{array}{l}10 \mathrm{mM} \\
\mathrm{NH}_{4} \mathrm{OAC} \text { in } \\
\text { gradient }\end{array}$ & 6.0 & [15] \\
\hline $\begin{array}{l}\mathrm{C} 18(4 \mu \mathrm{m}) / 8 \mathrm{~mm} \times 100 \\
\mathrm{~mm} / \text { b.d. }\end{array}$ & DAD & $493 / 546$ & $\mathrm{ACN}$ & $\begin{array}{l}50 \mathrm{mM} \\
\mathrm{NH}_{4} \mathrm{OAC} \text {, in } \\
\text { gradient }\end{array}$ & 7.0 & [25] \\
\hline $\begin{array}{l}\mathrm{C} 18(5 \mu \mathrm{m}) / 4.6 \mathrm{~mm} \times 150 \\
\mathrm{~mm} / 35^{\circ} \mathrm{C}\end{array}$ & FLD & $493 / 515$ & $\begin{array}{l}50 \mathrm{mM} \text { acetic } \\
\text { acid- } \\
\text { ammonium } \\
\text { acetate }(\mathrm{pH}=9) \\
\text { in a mixture of } \\
\text { methanol/water } \\
(30 / 70, v / v)\end{array}$ & $\begin{array}{l}4 \mathrm{mM} \\
\text { triethylamine in } \\
\text { methanol, in } \\
\text { gradient }\end{array}$ & $\begin{array}{l}7.8-8.4 \\
\text { (depending on } \\
\mathrm{pH} \text { ) }\end{array}$ & [23] \\
\hline $\begin{array}{l}\mathrm{C} 18(2,6) / \\
4.6 \mathrm{~mm} \times 150 \mathrm{~mm} / 35^{\circ} \mathrm{C}\end{array}$ & FLD & $493 / 515$ & $\begin{array}{l}\text { mixture of } \mathrm{ACN} \\
8.4 ; \text { prepared fror } \\
\text { ammonium aceta } \\
\text { aqueous solution }\end{array}$ & $\begin{array}{l}\text { nd buffer }(\mathrm{Ph}= \\
0.5 \mathrm{M} \\
\text { e and } 3 \mathrm{M} \mathrm{NaOH} \\
\text { in gradient }\end{array}$ & 9.0 & [9] \\
\hline
\end{tabular}

The selection of separation conditions is usually a difficult and laborious process. Often, it is not possible to separate analytes in an isocratic system (constant mobile phase composition), and thus, a gradient (step or continuous change in mobile phase composition) has to be applied. Currently, the most commonly used separation systems by high-performance liquid chromatography are the so-called reversed-phase (RP) systems, most often using the stationary phase of RP-18 type, i.e., silica gel modified with an octadecyl group.

The aim of this study was to develop a sufficiently sensitive, selective and reproducible method for the determination of uranine in formation waters. The main problem in the determination of uranine in this type of matrix is to obtain a sufficiently low quantification limit for the complexity of the matrix analyzed. The developed method for uranine determination is useful for this purpose. It has good repeatability and accuracy, and is also selective.

This paper presents the optimization and validation results of a method for the determination of uranine in formation water samples. This is a liquid chromatographic method that uses a fluorescence detector, preceded by extraction of the analyte to a solid phase (SPE). The applied chromatographic column EVO C18 allowed effective separation of the analyte in a short time. The aim of this study was to develop a sufficiently sensitive, selective and reproducible method for the determination of uranine in formation waters. The main 
problem in the determination of uranine in this type of matrix is to obtain a sufficiently low quantification limit for the complexity of the matrix analyzed. The developed method for uranine determination is useful for this purpose. It has good repeatability and accuracy, and it is selective. As part of the method validation, the extraction efficiency was checked and the uncertainty budget of the analytical method was estimated. It was assumed that the method will be useful if the expanded uncertainty determined for the whole range of the method's concentration does not exceed 30\%. This is due to the multi-stage sample preparation process and the complexity of the matrix.

\section{Materials and Methods}

The first stage of the analysis was the separation of uranine from formation water samples using solid phase extraction. High-performance liquid chromatography with fluorescence detection (HPLC/FLD) was used to determine the uranine concentration. The equipment and reagents used for the tests are described below.

\subsection{Equipment}

A Merck LaChrom liquid chromatograph equipped with a fluorescence detector (L-7485), which is sensitive to fluorescent compounds, an automatic sample feeder, a twochannel pump, a column thermostat, and a data acquisition system were used for the analyses. A Kintex $5 \mu \mathrm{m}$ EVO C18 $100 \AA$ analytical column with the dimensions of $250 \mathrm{~mm}$ (L) $\times 3 \mathrm{~mm}$ (int.ø.), which was filled with silica gel modified with C18 (octadecyl) groups and EVOC18 precolumn, was used for the analyses. The diameter of the filling grains was $5 \mu \mathrm{m}$. The mobile phase was a mixture of acetonitrile and buffer dispensed onto the chromatograph in gradient. More details about the gradient can be found in the chapter 2.4. The column was operated at $35^{\circ} \mathrm{C}$. This column features a novel design that allows for better efficiencies when operating at lower pressures and over a very wide mobile phase $\mathrm{pH}$ range. The sample volume used for chromatographic analysis was $20 \mu \mathrm{L}$. The excitation wavelength was 476 and the emission wavelength was $515 \mathrm{~nm}$. This is the wavelength most commonly used for the determination of uranine. The total chromatographic analysis time was $18 \mathrm{~min}$.

\subsection{Solid Phase Extraction (SPE)}

Samples were subjected to solid phase extraction (SPE) prior to chromatographic analysis. Strata-X/Strata-XL Reversed Phase for Neutral Compounds extraction columns, obtained from Phenomenex, were used for SPE extraction at quantities of $200 \mathrm{mg} / 6 \mathrm{~mL}$. The columns were wetted and conditioned for activation with $1 \mathrm{~mL}$ methanol, then washed with $1 \mathrm{~mL}$ water at a flow rate of $4-6 \mathrm{~mL} / \mathrm{min}$.

The analyzed sample was filtered through a glass fiber filter (Whatman Glass Microfiber Filters GF / A) and acidified with 95-99.9\% acetic acid (Merck, Darmstadt, Germany) to $\mathrm{pH}=3.0$ before being applied to the column, and then passed through the extraction column at a flow rate of $1-2 \mathrm{~mL} / \mathrm{min}$ (sorption of uranine on the bed). The sample volume was $10 \mathrm{~mL}$. Samples were acidified to $\mathrm{pH}=3.0$ before extraction because, according to the literature [22], SPE was most efficient at this $\mathrm{pH}$. The extraction column was then washed with $5 \mathrm{~mL}$ of $5 \%$ methanol (Merck, Darmstadt, Germany). The elution of uranine from the column was carried out with $4 \mathrm{~mL}$ of $2 \%$ formic acid purchased from Sigma Aldrich (St. Louis, MI, USA) in acetonitrile (Merck, Darmstadt, Germany), the elution was carried out into $5 \mathrm{~mL}$ volumetric flasks. The flasks were refilled with a solution of $2 \%$ formic acid in acetonitrile to a volume of $5 \mathrm{~mL}$. Uranine from Merck, Darmstadt, Germany was used for the study. The sample, prepared and concentrated in this way, was subjected to chromatographic analysis.

Before establishing the above SPE extraction conditions, optimization of the extraction parameters, such as the initial sample volume and the type of column used, among others, was carried out. A brief description of the process of selecting the extraction parameters to make the extraction as efficient as possible is presented later in this article. 


\subsection{Determining Optimal Conditions for Solid Phase Extraction (SPE)}

In determining the optimal conditions for the extraction of uranine into the solid phase, it was checked whether another type of Phenomenex extraction column was suitable for the isolation of uranine from liquid samples. The method of SPE extraction was identical for both checked types of columns (described in the previous section). The extraction columns Strata-Z-AW/Strata-XL-AW Weak Anion Exchange \& Reversed Phase (for acids with pKa $\leq 5)$ and Strata-X/Strata-XL Reversed Phase for Neutral Compounds by Phenomenex were used. Figure 1 shows the graphs obtained for standard uranine solutions subjected to SPE extraction using both described types of extraction columns.

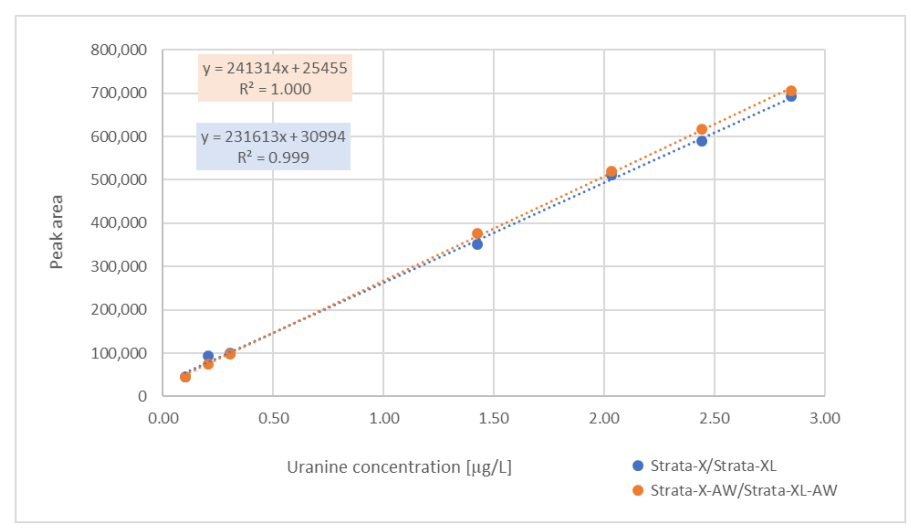

Figure 1. Standard curves obtained for the two types of extraction columns tested.

At the concentration range of $0.1-2.8 \mu \mathrm{g} / \mathrm{L}$, the obtained graphs took the form of a linear function. Both types of tested columns were suitable for the extraction of uranine to the solid phase. Due to the higher availability, Strata-X/Strata-XL Reversed Phase for Neutral Compounds columns from Phenomenex were used for the studies performed in this research.

Sample volume is an important parameter for the efficient isolation of analytes from samples during SPE extraction. In order to select optimum sample volume for extraction, tests were carried out on samples of formation waters with a uranine concentration of $0.4 \mu \mathrm{g} / \mathrm{L}$. Extractions were performed for 3 series of samples with initial volumes of $10 \mathrm{~mL}$, $25 \mathrm{~mL}$ and $50 \mathrm{~mL}$, respectively. The results obtained are summarized in Table 2.

Based on the study, the optimal sample volume for SPE extraction was found to be $10 \mathrm{~mL}$. The mean recovery for the results obtained using this volume was $100 \%$. The standard deviation for this volume was $0.022 \mu \mathrm{g} / \mathrm{L}$.

As part of the determination of suitable conditions for uranine extraction from formation water samples, chromatographic analyses of concentrated samples, obtained after SPE extraction with an inert gas stream, were also performed. However, the results obtained for the concentrated samples were not reproducible; moreover, the concentration process significantly prolonged the whole analytical procedure. Therefore, this step was eliminated, and the only sample concentration method that was used during the study was applied to select the appropriate volume of sample used for extraction and the appropriate volume eluted from the column for SPE. 
Table 2. Results obtained when selecting the optimal sample volume for SPE extraction.

\begin{tabular}{|c|c|c|c|c|c|}
\hline $\begin{array}{l}\text { Sample Volume } \\
\text { Used for SPE, mL }\end{array}$ & $\begin{array}{l}\text { Uranine Concentration } \\
\text { in the Sample, } \mu \mathrm{g} / \mathrm{L}\end{array}$ & $\begin{array}{c}\text { Uranine Concentration } \\
\text { in the Sample after SPE, } \\
\mu \mathrm{g} / \mathrm{L}\end{array}$ & Recovery, \% & Mean Recovery, \% & $\begin{array}{c}\text { Standard } \\
\text { Deviation, } \mu \mathrm{g} / \mathrm{L}\end{array}$ \\
\hline \multirow{6}{*}{10} & \multirow{6}{*}{0.40} & 0.43 & 106 & \multirow{6}{*}{100} & \multirow{6}{*}{0.022} \\
\hline & & 0.43 & 107 & & \\
\hline & & 0.39 & 97 & & \\
\hline & & 0.39 & 97 & & \\
\hline & & 0.38 & 96 & & \\
\hline & & 0.38 & 96 & & \\
\hline \multirow{6}{*}{25} & \multirow{6}{*}{0.40} & 0.43 & 107 & \multirow{6}{*}{106} & \multirow{6}{*}{0.005} \\
\hline & & 0.42 & 104 & & \\
\hline & & 0.43 & 107 & & \\
\hline & & 0.43 & 106 & & \\
\hline & & 0.43 & 108 & & \\
\hline & & 0.42 & 105 & & \\
\hline \multirow{6}{*}{50} & \multirow{6}{*}{0.40} & 0.43 & 107 & \multirow{6}{*}{110} & \multirow{6}{*}{0.009} \\
\hline & & 0.42 & 106 & & \\
\hline & & 0.44 & 111 & & \\
\hline & & 0.44 & 110 & & \\
\hline & & 0.45 & 112 & & \\
\hline & & 0.44 & 111 & & \\
\hline
\end{tabular}

\subsection{Chromatographic Analysis}

While selecting the optimal conditions for the chromatographic analysis of uranine in formation water samples, the quality of chromatographic separation was tested for three different settings and method parameters, described as "Method 1", "Method 2" and "Method 3". The tested methods differed in terms of the mobile phase composition, gradient, flow rate and sample separation temperature. A summary of the chromatographic separation conditions for the three tested methods is presented in Table 3.

The most effective separation of uranine in the reservoir water samples was obtained when using the parameters assigned to "Method 3" (Table 3). The elements of the validation of "Method 3" are presented later in the article. The mobile phase for this method was a mixture of acetonitrile and buffer ( $50 \mathrm{mM}$ ammonium acetate- $3 \mathrm{M}$ sodium hydroxide) with $\mathrm{pH}=8.4$. The $\mathrm{pH}$ of the acetate buffer was adjusted to the desired value by the dropwise addition of a $3 \mathrm{M}$ aqueous sodium hydroxide solution, which was monitored with a $\mathrm{pH}$ meter. Before being used in the chromatographic analysis, the buffer solution was filtered through a glass fiber filter (Whatman Glass Microfiber Filters, GF/A) and degassed in an ultrasonic bath for one hour. Example chromatograms obtained for all three methods, "Method 1", "Method 2" and "Method 3", are shown in Figure 2A-C.

Table 3. Chromatographic analysis parameters used during optimization for Method 1, Method 2 and Method 3.

\begin{tabular}{|c|c|c|}
\hline \multicolumn{3}{|r|}{ Method 1} \\
\hline \multicolumn{2}{|l|}{$\begin{array}{l}\lambda \text { wavelength, } \\
\mathrm{nm}\end{array}$} & $\begin{array}{l}476(\lambda \text { of excitation) } \\
515 \text { ( } \lambda \text { of emission })\end{array}$ \\
\hline \multicolumn{2}{|c|}{ Sample volume, $\mu \mathrm{L}$} & 20 \\
\hline \multicolumn{2}{|l|}{ Column } & $\begin{array}{l}\text { Kintex } 5 \mu \mathrm{m} \text { EVO C18 } 100 \AA \text { with dimensions } 250 \mathrm{~mm}(\mathrm{~L}) \times 3 \mathrm{~mm} \text { (int.ø), including a precolumn } \\
\text { with a filling grain diameter of } 5 \mu \mathrm{m}\end{array}$ \\
\hline \multicolumn{2}{|c|}{ Temp. of column, ${ }^{\circ} \mathrm{C}$} & 35 \\
\hline \multirow{2}{*}{ Mobile phase } & A & TBA OH buffer in methanol $\mathrm{pH}=7.0$ \\
\hline & B & Water \\
\hline
\end{tabular}

Symbols used in the Table 3: V—flow velocity of mobile phase; $\lambda$-wavelength; Temp.-temperature; ACN—acetonitrile; TBA OH— tetrabutylammonium hydroxide; $\mathrm{NH}_{4} \mathrm{OAC}$-ammonium acetate. 
Table 3. Cont.

\begin{tabular}{|c|c|c|c|c|c|c|}
\hline \multirow{4}{*}{ Gradient } & Time, min & $0-3$ & \multicolumn{2}{|l|}{6} & 7 & $7-15$ \\
\hline & Phase A, \% & 35 & \multicolumn{2}{|l|}{70} & 35 & 35 \\
\hline & Phase B, \% & 65 & \multicolumn{2}{|l|}{30} & 65 & 65 \\
\hline & $\mathrm{V}, \mathrm{mL} / \mathrm{min}$ & 1 & \multicolumn{2}{|l|}{1} & 1 & 1 \\
\hline \multicolumn{7}{|c|}{ Method 2} \\
\hline \multicolumn{2}{|l|}{$\begin{array}{l}\lambda \text { wavelength, } \\
\mathrm{nm}\end{array}$} & \multicolumn{3}{|c|}{$\begin{array}{l}476 \text { ( } \lambda \text { of excitation) } \\
515 \text { ( } \lambda \text { of emission) }\end{array}$} & & \\
\hline \multicolumn{2}{|c|}{ Sample volume, $\mu \mathrm{L}$} & \multicolumn{3}{|l|}{20} & & \\
\hline \multicolumn{2}{|l|}{ Column } & \multicolumn{5}{|c|}{$\begin{array}{l}\text { Kintex } 5 \mu \mathrm{m} \text { EVO C18 } 100 \AA \text { with dimensions } 250 \mathrm{~mm}(\mathrm{~L}) \times 3 \mathrm{~mm} \text { (int.ø), including a precolumn } \\
\text { with a filling grain diameter of } 5 \mu \mathrm{m}\end{array}$} \\
\hline \multicolumn{2}{|c|}{ Temp. of column, ${ }^{\circ} \mathrm{C}$} & \multicolumn{5}{|l|}{30} \\
\hline \multirow{2}{*}{ Mobile phase } & A & \multicolumn{5}{|l|}{ can } \\
\hline & B & \multicolumn{5}{|c|}{$50 \mathrm{mM} \mathrm{NH}_{4} \mathrm{OAC}$ buffer with $\mathrm{pH}=8.4$} \\
\hline \multirow{4}{*}{ Gradient } & Time, $\min$ & 0 & 5 & 10 & $12-14$ & $14-16$ \\
\hline & Phase A, \% & 10 & 30 & 60 & 90 & 10 \\
\hline & Phase B, \% & 90 & 70 & 40 & 10 & 90 \\
\hline & $\mathrm{V}, \mathrm{mL} / \mathrm{min}$ & 1 & 1 & 1 & 1 & 1 \\
\hline \multicolumn{7}{|c|}{ Method 3} \\
\hline \multicolumn{2}{|l|}{$\begin{array}{l}\lambda \text { wavelength, } \\
\text { nm }\end{array}$} & \multicolumn{3}{|c|}{$\begin{array}{l}476 \text { ( } \lambda \text { of excitation) } \\
515 \text { ( } \lambda \text { of emission) }\end{array}$} & & \\
\hline \multicolumn{2}{|c|}{ Sample volume, $\mu \mathrm{L}$} & \multicolumn{3}{|l|}{20} & & \\
\hline \multicolumn{2}{|l|}{ Column } & \multicolumn{5}{|c|}{$\begin{array}{l}\text { Kintex } 5 \mu \mathrm{m} \text { EVO C18 } 100 \AA \text { with dimensions } 250 \mathrm{~mm}(\mathrm{~L}) \times 3 \mathrm{~mm} \text { (int.ø), including a precolumn } \\
\text { with a filling grain diameter of } 5 \mu \mathrm{m}\end{array}$} \\
\hline \multicolumn{2}{|c|}{ Temp. of column, ${ }^{\circ} \mathrm{C}$} & \multicolumn{5}{|l|}{35} \\
\hline \multirow{2}{*}{ Mobile phase } & A & \multicolumn{5}{|l|}{ can } \\
\hline & B & $50 \mathrm{~m}$ & buffer wi & & & \\
\hline & Time, $\min$ & $0-1$ & 10 & $11-15$ & 17 & 18 \\
\hline Gradient & Phase A, \% & 10 & 15 & 99 & 10 & 10 \\
\hline & Phase B, \% & 90 & 85 & 1 & 90 & 90 \\
\hline & $\mathrm{V}, \mathrm{mL} / \mathrm{min}$ & 0.8 & 0.8 & 1.5 & 1.3 & 0.8 \\
\hline
\end{tabular}

Symbols used in the Table 3: V—flow velocity of mobile phase; $\lambda$-wavelength; Temp.—-temperature; $\mathrm{ACN}$-acetonitrile; TBA OHtetrabutylammonium hydroxide; $\mathrm{NH}_{4} \mathrm{OAC}$-ammonium acetate. 

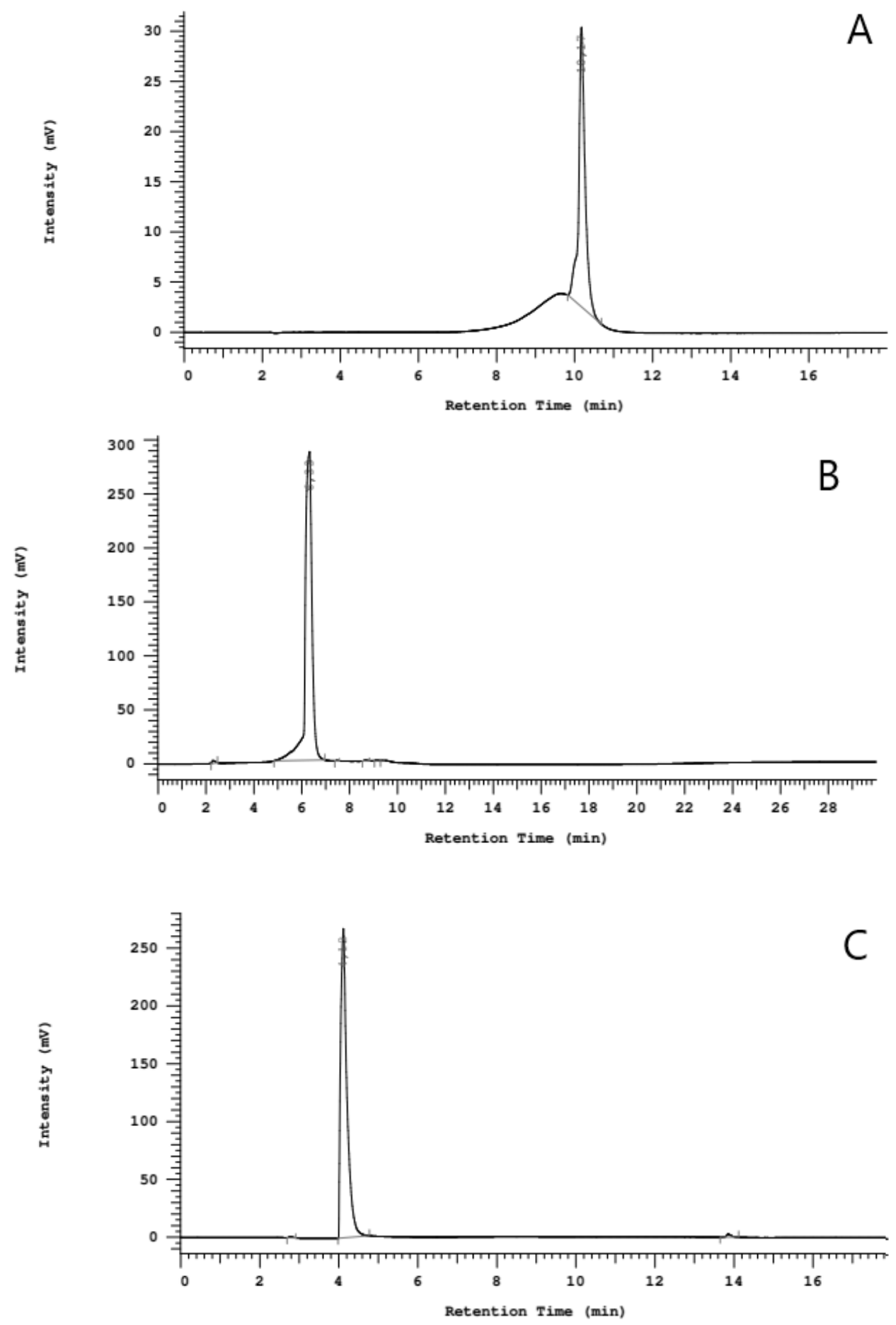

Figure 2. Chromatograms obtained for determination of uranine concentration in formation water samples by HPLC, for "Method 1" (A); "Method 2" (B) and "Method 3" (C).

\section{Results}

For the developed method of uranine determination in formation waters, selected validation parameters were established. The results obtained and the method of determination of these parameters are presented below.

\subsection{Defining the Working Scope of the Developed Method}

The working range of a measurement method is defined as the interval between the lowest and the highest concentration (including these concentrations) that can be 
determined by a given measurement method with assumed reproducibility, accuracy and linearity. In instrumental methods, it is generally equated with the range of applicability of a standard curve. It is assumed that the lower limit of the working range usually corresponds to the limit of quantification, while the maximum concentration expected in routine analyses should be around the middle of the adopted working range. In this study, it was initially assumed that the working range of the method would be between 0.03 and $2.80 \mu \mathrm{g} / \mathrm{L}$, and this range was checked for reproducibility and linearity, as described later in this paper.

The initial step in the determination of uranine in formation water samples prior to chromatographic analysis is solid phase extraction (SPE), during which the sample is concentrated. The efficiency of this step was checked and it turned out that recoveries of about $50 \%$ were obtained. This low efficiency of the SPE extraction step could be due to the high salinity of the samples. Therefore, using a standard curve prepared without the SPE extraction step is not an appropriate solution. To reduce the error due to the standardization step, all standard solutions were subjected to SPE in the same way as the analyzed real samples.

For standardization, a series of solutions were prepared with uranine concentrations ranging from 0.03 to $2.80 \mu \mathrm{g} / \mathrm{L}$. The solutions were acidified to $\mathrm{pH}=3.0 \mathrm{using} 99 \%$ acetic acid. This was followed by solid phase extraction and chromatographic analysis. The results obtained from the standardization are shown in Table 4.

Table 4. Parameters of obtained standardization curves and results of calculations performed to assess linearity.

\begin{tabular}{ccccc}
\hline $\begin{array}{c}\text { Standardization } \\
\text { Curve Number/ } \\
\text { Equation of } \\
\text { Curve }\end{array}$ & $\begin{array}{c}\text { Linear Correlation } \\
\text { Coefficient } \mathbf{r}\end{array}$ & $\begin{array}{c}\text { Number of Points } \\
\text { of the Curve } \\
\mathbf{N}\end{array}$ & $\mathbf{t}_{\mathbf{r}}$ & $\begin{array}{c}\mathbf{t}_{\text {kryt }} \\
\text { (for a 95\% Confidence } \\
\text { Interval and } \mathbf{n}-2)\end{array}$ \\
\hline $\begin{array}{c}\mathrm{y}=2419.8 \mathrm{x}+91.79 \\
\mathrm{y}=2397.6 \mathrm{x}+\end{array}$ & 0.9993 & 7 & 61.4 & 2.57 \\
288.49 & 0.9998 & 9 & 142.8 & 2.36 \\
$\mathrm{y}=2324.2 \mathrm{x}+$ & 0.9994 & 7 & 64.5 & 2.57 \\
357.86 & & 7 & & \\
\hline
\end{tabular}

Correlation coefficients close to unity confirm the strong linear dependence of the method over a range of uranine concentrations from 0.03 to $2.80 \mu \mathrm{g} / \mathrm{L}$. The determined parameters of the Student's $t$-test $\left(t_{r}\right)$ do not exceed the critical values $\left(t_{\text {kryt }}\right)$.

\subsection{Determination of the Limit of Detection and Limit of Quantification of the Method}

As part of the validation of the method for the determination of uranine in formation water samples, the detection and quantification limits were established.

To determine the limit of quantification, the concentration of uranine was determined in a series of blank samples (redistilled water without analyte, with concentrated acetic acid, $\mathrm{pH}=3.0$ ) that underwent the entire analytical procedure (including SPE extraction). The series contained eight samples. The obtained results are collected in Table 5. 
Table 5. Results of measurements and calculations obtained during the determination of the limit of detection and quantification of the chromatographic method for the determination of uranine.

\begin{tabular}{ccccc}
\hline $\begin{array}{c}\text { Area of the } \\
\text { Chromatographic Peak } \\
\text { Obtained for the Blank, } \\
\mathbf{m V} \cdot \mathbf{s}\end{array}$ & $\begin{array}{c}\text { Arithmetic } \\
\text { Mean, } \mathbf{m V} \cdot \mathbf{s}\end{array}$ & $\begin{array}{c}\text { Standard } \\
\text { Deviation, } \\
\mathbf{m V} \cdot \mathbf{s}\end{array}$ & $\begin{array}{c}\text { Quantification } \\
\text { Limit of the } \\
\text { Method, } \mu \mathrm{g} / \mathrm{L}\end{array}$ & $\begin{array}{c}\text { Detection } \\
\text { Limit of the } \\
\text { Method, } \mu \mathrm{g} / \mathrm{L}\end{array}$ \\
\hline $\begin{array}{c}123.90 \\
138.68\end{array}$ & & & \\
130.63 & 143.91 & 12.36 & 0.03 & \\
142.94 & & & \\
143.98 & & & \\
150.34 & & & \\
156.31 & & & \\
164.46 & & & \\
\hline
\end{tabular}

The determined quantification limit of the uranine analysis method in formation water samples was $0.03 \mu \mathrm{g} / \mathrm{L}$, while the detection limit was $0.008 \mu \mathrm{g} / \mathrm{L}$.

\subsection{Evaluation of Reproducibility of the Method}

Reproducibility is the precision of results obtained under the same measurement conditions (given laboratory, person performing the measurement, measuring instrument and reagents). It is usually expressed by standard deviation of reproducibility, variance, coefficient of variation or relative standard deviation.

Validation of the present method included the determination of reproducibility for three concentration levels $(0.03 \mu \mathrm{g} / \mathrm{L}, 0.20 \mu \mathrm{g} / \mathrm{L}$ and $2.50 \mu \mathrm{g} / \mathrm{L})$. Three series of uranine solutions of assumed concentrations were prepared, solid phase extractions were performed, and the uranine concentration was calculated using one of the previously determined standard curve equations (standardization was performed for each measurement series). The arithmetic mean, standard deviation (SD) and coefficient of variation (CV) were calculated for the results obtained. The results of measurements and calculations are summarized in Table 6.

Table 6. Evaluation of the reproducibility of the method for determination of uranine by HPLC/FLD based on the results obtained for standard solutions and real samples.

\begin{tabular}{ccccc}
\hline $\begin{array}{c}\text { Assumed Uranine } \\
\text { Concentration or Real } \\
\text { Sample Symbol, } \mu \mathrm{g} / \mathrm{L}\end{array}$ & $\begin{array}{c}\text { Arithmetic Mean of the } \\
\text { Determined Uranine } \\
\text { Concentrations, } \mu \mathrm{g} / \mathrm{L}\end{array}$ & $\mathrm{SD}, \boldsymbol{\mu g} / \mathrm{L}$ & $\mathbf{C V}, \mathbf{\%}$ \\
\hline \multirow{4}{*}{ Standards } & 0.030 & 0.024 & 0.002 & 8.90 \\
& 0.200 & 0.190 & 0.021 & 10.7 \\
\multirow{4}{*}{ Real samples } & 2.50 & 2.30 & 0.280 & 12.2 \\
\hline & AU1 & 0.370 & 0.044 & 11.8 \\
& AU2 & 0.320 & 0.004 & 1.26 \\
& AU3 & 0.040 & 0.005 & 14.6 \\
\hline
\end{tabular}

Prior to the calculations, the results of each run used to determine reproducibility were checked for the presence of gross errors using the Q-Dixon test. Since this test did not indicate the presence of results with gross error, all results within each series were used to calculate the mean value and standard deviation.

Because aqueous (non-matrix) solutions are mostly overly homogeneous, the reproducibility of the method for real samples was also evaluated. For this purpose, formation water samples were extracted and uranine concentration was determined by liquid chromatography with fluorescence detection. The samples were frozen and stored in the dark before analysis. Depending on the volume of real samples available in the laboratory, 
the analyses were performed 4-10 times. Then, the arithmetic mean of the obtained results, standard deviation and coefficient of variation were calculated. The results of tests and calculations are presented in Table 6. The uranine determination results obtained for real samples are characterized by high reproducibility (CV less than 15\%).

\subsection{Determination of Method Selectivity}

The next step in validating the method was to determine its selectivity and the effect of the matrix on the assay results. Selectivity is the ability of a method to determine a specific analyte in the presence of other sample matrix components under given conditions. The selectivity of a method is established on the basis of the results of determination of samples containing various components suspected of influencing the measurement of the content of a given analyte. The evaluation of the results consists of determining to what extent the substances present in the test sample influence the result of the analyte determination. The presence of interferents can decrease or increase the result. The selectivity of the method was evaluated by determining uranine in real (matrix) samples to which a known concentration of uranine was added. The samples (AU3, AU4) enriched with the standard $(0.1 \mu \mathrm{g} / \mathrm{L})$ were subjected to the whole analytical procedure. The concentration of inorganic anions, which may affect the result of uranine determination, was determined by ion chromatography. The results obtained during the studies and the calculations made on their basis are presented in Table 7. The tests were performed six times.

Table 7. Measurement and calculation results obtained from the method selectivity evaluation.

\begin{tabular}{|c|c|c|c|c|c|c|c|c|}
\hline \multirow{2}{*}{$\begin{array}{l}\text { Sample } \\
\text { Number }\end{array}$} & \multirow{2}{*}{$\begin{array}{l}\text { Concentration of } \\
\text { Uranine Added to } \\
\text { the Sample, } \mu \mathrm{g} / \mathrm{L}\end{array}$} & \multirow{2}{*}{$\begin{array}{c}\text { Mean } \\
\text { Concentration } \\
\text { of Uranine, } \mu \mathrm{g} / \mathrm{L}\end{array}$} & \multicolumn{4}{|c|}{ Concentration } & \multirow{2}{*}{$\begin{array}{l}\mathrm{SD}, \\
\mu \mathrm{g} / \mathrm{L}\end{array}$} & \multirow{2}{*}{$\begin{array}{c}\text { Mean } \\
\text { Recovery, } \\
\% \\
\end{array}$} \\
\hline & & & $\begin{array}{c}\text { Chlorides, } \\
\text { g/L }\end{array}$ & $\begin{array}{c}\text { Bromides, } \\
\mathrm{mg} / \mathrm{L}\end{array}$ & $\begin{array}{l}\text { Sulphates, } \\
\text { mg/L }\end{array}$ & $\begin{array}{l}\text { Fluorides, } \\
\text { mg/L }\end{array}$ & & \\
\hline AU3 & 0.10 & 0.09 & 211.6 & 2.466 & 266.7 & $<20$ & 0.005 & 88 \\
\hline AU4 & 0.10 & 0.10 & 223.7 & 2.179 & 172.3 & $<20$ & 0.006 & 100 \\
\hline
\end{tabular}

The obtained results showed that the presence of high contents of inorganic anions in the sample does not influence the result of uranine determination by the developed method. The validated method for uranine determination in formation water samples is selective.

\subsection{Testing the Persistence of Uranine in Formation Water Samples during Storage}

AU5 and AU6 formation water samples were used to determine the stability of uranine over time. The samples were subjected to time exposure with limited access to light and the effect of storage temperature on the stability of the samples for 1-4 weeks was checked. Some of the prepared samples were cooled to $1-5^{\circ} \mathrm{C}$, and the rest were frozen. The samples were stored in tightly closed plastic bottles wrapped with aluminum foil to limit the access of light. The results of the tests are presented in Table 8.

Uranine decomposes when exposed to light [13-16]. Visible light also affects the color of uranine solutions. The color intensity of low-concentration uranine solutions decreases with time [13], whereas in the case of solutions of higher concentration, the color of solutions changes from green-yellow to orange. The change in color of the uranine solution under the influence of light is presented on Figure 4.

In solid form or as a solution at high concentration, uranine is dark red in color (Figure 3A). Uranine only shows green-yellow fluorescence at higher dilution [9] (Figure 3B). 
Table 8. Results obtained in determining the stability of enriched real samples during storage.

\begin{tabular}{|c|c|c|c|c|c|c|}
\hline $\begin{array}{l}\text { Sample } \\
\text { Number }\end{array}$ & $\begin{array}{l}\text { Sample Storage } \\
\text { Conditions }\end{array}$ & $\begin{array}{l}\text { Sample Storage } \\
\text { Time, Weeks }\end{array}$ & $\begin{array}{c}\text { Baseline } \\
\text { Concentration of } \\
\text { Uranine in the Sample, } \\
\mu \mathrm{g} / \mathrm{L}\end{array}$ & $\begin{array}{c}\text { The Average Concentration of } \\
\text { Uranine in a Sample Determined } \\
\text { after a Specified Storage Time, } \\
\mu \mathrm{g} / \mathrm{L}\end{array}$ & $\begin{array}{l}\mathrm{SD} \\
\mu \mathrm{g} / \mathrm{L}\end{array}$ & $\begin{array}{c}\text { Recovery, } \\
\%\end{array}$ \\
\hline & \multirow{4}{*}{$\begin{array}{l}\text { refrigerated }\left(1-5^{\circ} \mathrm{C}\right) \text {, } \\
\text { in the absence of light }\end{array}$} & 2 & 0.40 & 0.37 & 0.011 & 93 \\
\hline AU5 & & 3 & 0.40 & 0.41 & 0.018 & 102 \\
\hline \multirow{2}{*}{ AU6 } & & 1 & 0.24 & 0.27 & 0.007 & 109 \\
\hline & & 4 & 0.24 & 0.29 & 0.010 & 120 \\
\hline \multirow{2}{*}{ AU5 } & frozen, in the absence & 2 & 0.40 & 0.40 & 0.009 & 100 \\
\hline & of light & 3 & 0.40 & 0.39 & 0.009 & 97 \\
\hline
\end{tabular}

A

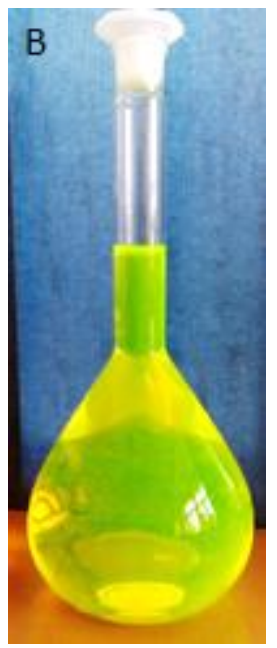

Figure 3. Solid uranine (A) and a $100 \mathrm{mg} / \mathrm{L}$ aqueous solution of uranine (B) (photo M. Gajec).

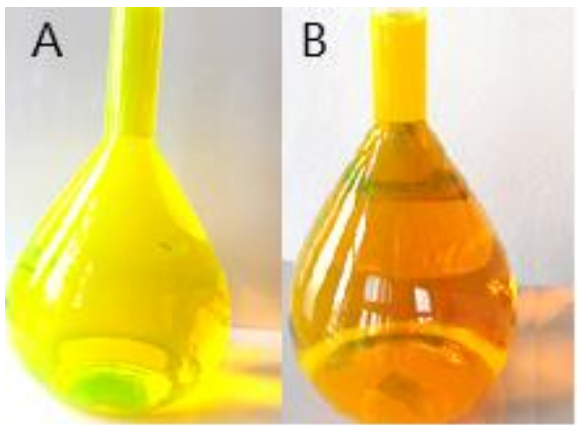

Figure 4. Change in color of uranine solution under the influence of light. Figure left-freshly prepared aqueous solution of uranine with a concentration of $100 \mathrm{mg} / \mathrm{L}(\mathbf{A})$, and the same solution exposed to light for 7 days (B) (photo: M. Gajec).

The stability of uranine in over-extracted samples was also checked. For this purpose, uranine concentration was determined again in standard solutions prepared for standardization curve determination and subjected to SPE extraction after one week of storage in a refrigerator in the absence of light. The standardization curve for freshly prepared solutions and the curve for solutions subjected to extraction and stored for seven days is shown in Figure 5. 


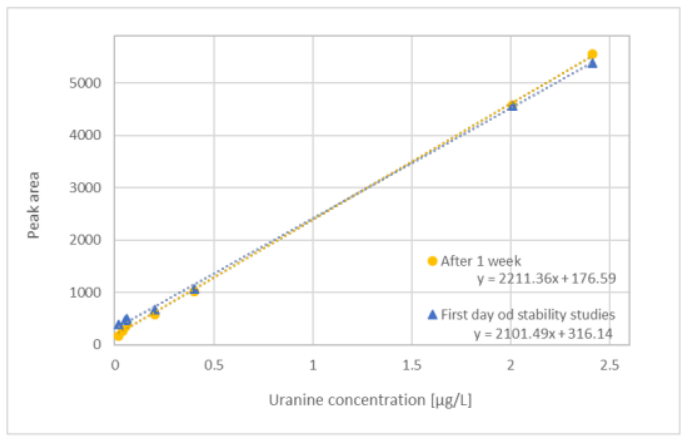

Figure 5. Results obtained when evaluating the stability of standard solutions subjected to extraction (measurements taken immediately after extraction and one week after extraction using SPE).

A decrease in uranine concentrations was observed, which was particularly evident for the over-extracted standard samples with uranine concentrations of $0.03-0.06 \mu \mathrm{g} / \mathrm{L}$.

To assess the stability of the matrix samples (extracted), the over-extracted real sample (labeled AU6) was stored in a refrigerator $\left(1-5^{\circ} \mathrm{C}\right)$ in the absence of light and its uranine concentration was measured again after 7 days of storage. The uranine concentration in a sample determined after 7 days was $0.250 \mu \mathrm{g} / \mathrm{L}$. The baseline concentration of uranine in the AU6 sample was $0.240 \mu \mathrm{g} / \mathrm{L}$. The recovery obtained for the sample was $104 \%$ (SD was $0.011 \mu \mathrm{g} / \mathrm{L}$ ). The AU6 sample stored for 7 days in a refrigerator at $1-5^{\circ} \mathrm{C}$ without light was found to be stable.

\subsection{Assessment of the Correctness of the Method}

In order to determine the correctness of the method, the relative error was calculated for the results obtained for uranine standard solutions. The obtained values are presented in Table 9.

Table 9. Results of measurements and calculations performed to determine the correctness of the method for determining uranine in liquid samples.

\begin{tabular}{cccc}
\hline $\begin{array}{c}\text { Assumed Uranine } \\
\text { Concentration, } \mu \mathrm{g} / \mathrm{L}\end{array}$ & $\begin{array}{c}\text { Arithmetic Mean of the Determined } \\
\text { Uranine Concentrations, } \mu \mathrm{g} / \mathrm{L}\end{array}$ & $\mathrm{SD}, \boldsymbol{\mu g} / \mathrm{L}$ & $\begin{array}{c}\text { Relative } \\
\text { Error, \% }\end{array}$ \\
\hline 0.030 & 0.024 & 0.001 & 19.2 \\
0.200 & 0.190 & 0.002 & 2.59 \\
2.50 & 2.30 & 0.043 & 7.30 \\
\hline
\end{tabular}

On the basis of the conducted research, it can be concluded that the method of uranine determination in formation waters is correct. The determined relative error was the highest for the uranine concentration of $0.030 \mu \mathrm{g} / \mathrm{L}$. This concentration was at the limit of quantification of the method. This error could have resulted from the complex and multistage process of preparing the sample for testing. For the remaining concentrations, the relative error did not exceed $10 \%$ (Table 9).

\subsection{Estimating the Uncertainty of the Method}

The uncertainty of measurement is the numerical interval that characterizes the variation in the values obtained for the property being measured and defines the range within which the true value of the measurand may be found with a specified probability. A primary source of measurement uncertainty is random errors that cannot be avoided in a measurement. Estimation of the magnitude of random errors before measurement prevents their unpredictable character and their occurrence causes the results to scatter around the mean value for a series of repeated measurements [27,28]. On the basis of the performed estimates, it can be concluded that the two main components of uncertainty of the uranine determination method in reservoir water samples are: the uncertainty resulting 
from the sample preparation stage using SPE $\left(\mathrm{W}_{\mathrm{SPE}}\right)$ and the uncertainty resulting from repeatability $\left(\mathrm{W}_{\text {powt }}\right)$. Both uncertainty components depend on the uranine concentration in the samples, and for a concentration range of $2.1-2.8 \mu \mathrm{g} / \mathrm{L}$, they are $12.2 \%$ and $4.62 \%$, respectively (Table 10).

Table 10. Sources and estimated values of uncertainty components characterized for the HPLC/FLD method of uranine determination in formation water samples.

\begin{tabular}{|c|c|c|c|c|}
\hline Stage of the Uranine Determination Procedure & Sources of Uncertainty & Symbol & Concentration Range & Relative Uncertainty, $\%$ \\
\hline \multirow[b]{2}{*}{ Sample collection and storage } & Sample collection & \multicolumn{3}{|c|}{ Not determined } \\
\hline & $\begin{array}{ll} & \text { Analyte degradation (light) } \\
& \text { Conditions and sample storage time before analysis }\end{array}$ & $\mathrm{W}_{\text {stab }}$ & $0.030-2.8 \mu \mathrm{g} / \mathrm{L}$ & 4.04 \\
\hline \multirow[t]{2}{*}{$\begin{array}{l}\text { Preliminary sample preparation(draining, } \\
\text { SPE/concentration) }\end{array}$} & $\begin{array}{ll}\text { - } & \text { Incomplete sorption of analyte } \\
\text { Incomplete elution of analyte } \\
\text { Solvent purity }\end{array}$ & \multirow[t]{2}{*}{$\mathrm{w}_{\mathrm{SPE}}$} & $0.030-2.0 \mu \mathrm{g} / \mathrm{L}$ & 2.89 \\
\hline & $\begin{array}{l}\text { Uncertainty of volume measurement } \\
\quad \text { Losses due to sample draining }\end{array}$ & & $2.1-2.8 \mu \mathrm{g} / \mathrm{L}$ & 4.62 \\
\hline Standardization & $\begin{array}{ll}\text { - } & \text { Effect of the preparation of standard solutions by successive dilutions } \\
\left(w_{w}\right) & \text { Uncertainty of calibration and application of linear regression method } \\
\left(w_{x p r}\right) & \end{array}$ & $\mathrm{w}_{\mathrm{kal}}$ & $0.030-2.8 \mu \mathrm{g} / \mathrm{L}$ & 3.4 \\
\hline \multirow{2}{*}{ Chromatographic analysis } & $\begin{array}{l}\text { Uncertainty of peak area reading of analyte } \\
\quad \text { Uncertainty of sample volume input }\end{array}$ & \multirow[t]{2}{*}{$\mathrm{W}_{\text {powt }}$} & $0.030-2.0 \mu \mathrm{g} / \mathrm{L}$ & 10.7 \\
\hline & $\begin{array}{l}\text { Uncertainty of moble phase volume and pH } \\
\text { Reproducibility of results obtained for a given sample }\end{array}$ & & $2.1-2.8 \mu \mathrm{g} / \mathrm{L}$ & 12.2 \\
\hline \multirow{2}{*}{ Complex uncertainty } & & \multirow{2}{*}{$\mathrm{W}_{\mathrm{złoz}}$} & $0.030-2.0 \mu \mathrm{g} / \mathrm{L}$ & 12.3 \\
\hline & & & $2.1-2.8 \mu \mathrm{g} / \mathrm{L}$ & 14.2 \\
\hline \multirow{2}{*}{$\begin{array}{l}\text { Expanded uncertainty } \\
(\mathrm{k}=2 \text {, for } 95 \% \text { confidence level })\end{array}$} & & \multirow{2}{*}{$\mathrm{U}$} & $0.030-2.0 \mu \mathrm{g} / \mathrm{L}$ & 24.6 \\
\hline & & & $2.1-2.8 \mu \mathrm{g} / \mathrm{L}$ & 28.4 \\
\hline
\end{tabular}

Table 10 shows the main sources of uncertainty characterized for the method of uranine determination using high-performance liquid chromatography with fluorescence detection together with estimated values of the uncertainty components of this determination.

The relative complex uncertainty was calculated from relation (1):

$$
\mathrm{W}_{\mathrm{zloz}}=\sqrt{\mathrm{W}_{\text {powt }}^{2}+\mathrm{W}_{\mathrm{kal}}^{2}+\mathrm{W}_{\mathrm{SPE}}^{2}+\mathrm{W}_{\mathrm{stab}}^{2}}
$$

in which:

$\mathrm{W}_{\text {powt }}$ - uncertainty related to the reproducibility of the method;

$\mathrm{W}_{\mathrm{kal}}$ - uncertainty of the standardization stage;

$\mathrm{W}_{\mathrm{SPE}}$ - uncertainty associated with SPE;

$\mathrm{W}_{\text {stab }}$ - uncertainty due to lack of stability of the analyte.

The expanded uncertainty of the method for the determination of uranine in formation water does not exceed $30 \%(\mathrm{k}=2,95 \%)$. The largest component in the uncertainty budget is related to reproducibility of analysis $(10.7 \%$ for concentrations of $0.030-2.0 \mu \mathrm{g} / \mathrm{L}$ and $12.2 \%$ for concentrations of $2.1-2.8 \mu \mathrm{g} / \mathrm{L}$ ).

\section{Discussion}

The process of uranine determination in formation waters is difficult not only because of the many steps involved, but also because of the complexity of the sample matrix. The limit of quantification for the developed method is low and amounts to $30 \mathrm{ng} / \mathrm{L}$. The determined quantification limit is not as low as the one given in the literature, e.g., for mine waters [24]; however, it is sufficient for the purposes of assessing the presence of the tracer in formation waters. Moreover, mine water is pumped from mines and usually contains impurities, some of which are in suspension, but the majority are soluble. They cause the water to be hard. The mine water often contains corrosive agents, such as acids or alkali. The mineralization of mine waters is lower than of formation waters, which may affect the range of uranine determination and the efficiency of its separation by SPE [29-31].

In this study, an improved method for the determination of uranine concentration was developed. 
The developed method-consisting of a two-stage separation of the analyte, i.e., initial purification by the SPE method with the use of appropriate sorption columns and the use of a column for HPLC separation with a different method of packing the C-18 bed (Kintex $5 \mu \mathrm{m}$ EVO C18 $100 \AA$ A with dimensions of $250 \mathrm{~mm}(\mathrm{~L}) \times 3$ mm (int.ø), including a precolumn with a filling grain diameter of $5 \mu \mathrm{m}$ ) -allows both the purification of the analyte from the matrix and the obtaining of the analysis result in a short time. The applied chromatographic column and parameters of the method made it possible to optimize the conditions of analyte separation in such a way that the obtained retention time of uranine was about $4.12 \mathrm{~min}$. This retention time is about 2 times shorter than that obtained for the methods described so far in the literature $[9,15,23,25]$.

The correlation coefficients of the calibration curves close to unity confirm the strong linear dependence of the method in the uranine concentration range from 0.03 to $2.80 \mu \mathrm{g} / \mathrm{L}$.

The validated method for uranine determination in formation water samples is selective. The obtained results showed that the presence of high contents of inorganic anions in the sample does not affect the result of uranine determination by the developed method. The interference effect caused by the presence in the analyzed sample of components accompanying the determined compound was not found.

The groups of organic compounds present in the formation water include: polycyclic aromatic hydrocarbons (PAHs), alkyl phenols, heterocyclic compounds, aromatic amines, long-chain fatty acids, alkylaromatic acids (such as alkylbenzenes and alkylbiphenyls) and aliphatic hydrocarbons. Most polycyclic aromatic hydrocarbons are fluorescent. This is due to the fact that delocalized electrons in aromatic rings can be easily excited, and the rigid structure does not allow for effective vibrational relaxation. The fluorescence spectra of individual polycyclic aromatic hydrocarbons depend on the position and the number of aromatic rings and are very characteristic. As the number of aromatic rings increases, the fluorescence spectrum and the emission peak wavelength are redshifted from the ultraviolet to the visible range. Fluorescence emission spectra (corresponding to the number of rings from one to four) can be found at such wavelengths as $275-320 \mathrm{~nm}, 320-375 \mathrm{~nm}$, 375-425 nm and 425-556 nm. Moreover, the mixture of absorbing and fluorescing polycyclic aromatic hydrocarbons in aqueous matrices becomes complex because of the energy degrading/quenching phenomena such as self-quenching, the reabsorption of emitted photons, and the absorption or transfer of the resonance energy of exciting photons before reaching the fluorescing zone [32]. PAHs constitute the dominant organic compound class present in formation water, and thus, their presence in formation water may affect the determination of uranine concentration by means of HPLC with a fluorescent detector, and their influence should be examined in further studies.

Stability tests on samples showed that frozen samples are more stable during storage than refrigerated samples. Freezing in the absence of light is the most appropriate method of storing uranine-containing samples prior to analysis. Plastic containers are suitable for storing uranine-containing formation water samples prior to analysis. A decrease in uranine concentrations was observed, which was particularly evident in the case of over-extracted standard samples with uranine concentrations of $0.03-0.06 \mu \mathrm{g} / \mathrm{L}$. Hence, we conclude that freezing the uranine samples prior to extraction is a better method to ensure stability during storage than storing the over-extracted and cooled samples in the absence of light. There was no mention of this in the available publications.

This study shows that the volume of formation water sample affects the determination of uranine. Based on the study, the optimal sample volume for SPE extraction was found to be $10 \mathrm{~mL}$. Larger volumes of formation water may cause lower precision during the concentration of uranine via solid phase extraction.

The method was found to be correct over the entire concentration range analyzed. The relative error determined for the lowest concentration had the highest value (19.2\%). The reason for the error may be due to the stage of preparation of standard solutions used to assess the reproducibility and correctness of the method, which was multi-step (weighing a small amount of uranine and diluting the standard solution obtained from the 
weighing several times). In addition, the actual concentration of uranine in the solutions used for the analysis and the assumed value resulting from the calculation may have differed slightly, which, at such a low concentration, may have caused a decrease in the accuracy of the results.

The estimated expanded uncertainty of the result of uranine determination by highperformance liquid chromatography with fluorescence detection, at a concentration level of $0.030-2.0 \mu \mathrm{g} / \mathrm{L}$, is $25 \%$ (for $95 \%$ confidence level and $\mathrm{k}=2$ ). The expanded uncertainty for the developed method does not exceed $30 \%$, which, due to the complexity of the analytical process, can be considered an acceptable value. The primary sources of uncertainty in sample analysis using the analytical procedure adopted are analyte losses occurring during sample preparation stages for analysis (SPE extraction and sample draining) as well as the reproducibility of analytical results.

\section{Conclusions}

Uranine is usually determined using spectrophotometric methods (with the application of spectrofluorimeters); however, in specific matrices such as highly saline formation waters, a more specific method of sample purification and separation must be applied.

Such a method is the method of liquid chromatography with fluorescence detection, developed and validated within the framework of conducted studies, preceded by the separation of analyte by means of SPE. The method allows for the determination of low concentrations of uranine ( $30 \mathrm{ng} / \mathrm{L}$ ) and, thanks to SPE, the separation of uranine from highly mineralized formation waters is possible. The development of a methodology that allows the determination of uranine content at such a low level of concentrations in saline samples that must be pre-purified is a significant result. In addition, the developed method allows the shortening of the analysis time, which saves time and the amount of reagents used during the analysis.

The main advantage of the proposed method compared with method proposed for seawater samples by Ikea et al. [23] is that it can be used for the determination of uranine content in formation water samples from the oil and gas industry, which are often unstable, have high inorganic anion concentrations and are characterized by a relatively complex matrix. Moreover, formation waters are much more varied in composition than seawater. In addition to sodium, potassium, magnesium, calcium and chloride, sulphate and carbonate ions, reservoir waters usually contain trace amounts of ions of other elements, such as: radium, strontium, copper, bromine, iodine, manganese, iron, mercury, lead, etc. The mineralization of formation water can be as high as $30,000 \mathrm{mg} / \mathrm{dm}^{3}$. Contact of formation waters with atmospheric air causes an increase in the oxidation-reduction potential of reservoir waters, which results in a change in the forms of occurrence of chemical compounds that may pass from soluble to insoluble compounds. This is the case with iron and manganese ions. During aeration, carbon dioxide is removed from the water, which increases the $\mathrm{pH}$ of the water. Therefore, they are matrices that are very difficult for analysis [33].

This method will also be applicable to uranine in matrices with a similar physicochemical composition, e.g., to assess groundwater flow in deformed carbonate aquifers or to characterize faults that act as barriers to horizontal groundwater flow. Deformations along faults in the shallow crust cause heterogeneity in anisotropy and permeability, which has a significant impact on processes such as the circulation of hydrothermal fluids, groundwater flow, and hydrocarbon migration.

Tracers are also indicated by structural geologists and hydrogeologists to study fault zone hydrogeology for the delineation of fluid flow paths [3,4]. Artificial tracers that are applied at the surface travel more than $100 \mathrm{~m}$ along the fault within weeks; therefore, the stability of the tracer in changing conditions, as well as its selectivity, are crucial [4]. The obtained results showed that the presence of high contents of inorganic anions in the sample does not affect the uranine concentration, and it is stable in different conditions, so it can be used for the intended purpose. 
The method validation process demonstrated that the developed method for uranine determination using high-performance liquid chromatography with fluorescence detection is suitable for the intended purpose. The validation of the method included an analysis of factors affecting the measurement result (sources of uncertainty), determination of the range of linearity of the standard curve, determination of the limit of quantification of the method, and verification of the reproducibility, selectivity, stability and correctness achieved.

Author Contributions: Conceptualization, A.K., M.G. and E.K.-Z.; methodology, A.K. and M.G.; formal analysis, A.K. and M.G.; investigation, A.K.; writing-original draft preparation, A.K., E.K.-Z. and M.G.; writing-review and editing, E.K.-Z., A.K. and M.G.; visualization, A.K.; supervision, E.K.-Z. and M.G. All authors have read and agreed to the published version of the manuscript.

Funding: The research received funding as a part of the statutory work commissioned by the Ministry of Science and Higher Education, order no. 0070/GE/17, archival number DK-4100-0057/17.

Institutional Review Board Statement: Not applicable.

Informed Consent Statement: Not applicable.

Data Availability Statement: All data is available at the Department of Environmental Protection of the Oil and Gas Institute-National Research Institute in Krakow.

Conflicts of Interest: The authors declare no conflict of interest.

\section{References}

1. Such, J. Możliwości wykorzystania znaczników chemicznych w krajowym górnictwie nafty i gazu. Nafta-Gaz 2010, 7, 621-629.

2. Tayyib, D.; Abdulaziz, A.-Q.; Kokal, S.; Huseby, O. Overview of Tracer Applications in Oil and Gas Industry. In Proceedings of the SPE Kuwait Oil \& Gas Show and Conference, Mishref, Kuwait, 13-16 October 2019. [CrossRef]

3. Medici, G.; Smeraglia, L.; Torabi, A.; Botter, C. Review of modeling approaches to groundwater flow in deformed car-bonate aquifers. Groundwater 2021, 59, 334-351. [CrossRef] [PubMed]

4. Bense, V.; Gleeson, T.; Loveless, S.; Bour, O.; Scibek, J. Fault zone hydrogeology. Earth-Sci. Rev. 2013, 127, 171-192. [CrossRef]

5. Serres-Piole, C.; Preud'Homme, H.; Moradi-Tehrani, N.; Allanic, C.; Jullia, H.; Łobiński, R. Water tracers in oilfield applications: Guidelines. J. Pet. Sci. Eng. 2012, 98-99, 22-39. [CrossRef]

6. Coronado, M.; Ramírez-Sabag, J. Analytical model for tracer transport in reservoirs having a conductive geological fault. J. Pet. Sci. Eng. 2008, 62, 73-79. [CrossRef]

7. Gombert, P.; Biaudet, H.; De Sèze, R.; Pandard, P.; Carré, J. Toxicity of fluorescent tracers and their degradation byproducts. Int. J. Speleol. 2017, 46, 23-31. [CrossRef]

8. Cao, V.; Schaffer, M.; Taherdangkoo, R.; Licha, T. Solute Reactive Tracers for Hydrogeological Applications: A Short Review and Future Prospects. Water 2020, 12, 653. [CrossRef]

9. Blom, A.; Chukharkina, A.; Hallbeck, L.; Johansson, L. Microbial, Chemical and Physical Influences on Uranine Fluorescence Measurements; Report R-15-08; Swedish Nuclear Fuel and Waste Management Co.: Stockholm, Sweden, 2016; ISSN 1402-3091.

10. Zuber, A. Metody Znacznikowe w Badaniach Hydrogeologicznych; Poradnik Metodyczny; Oficyna Wydawnicza Politechniki Wrocławskiej: Wrocław, Poland, 2007.

11. Cowie, R.; Williams, M.W.; Wireman, M.; Runkel, R.L. Use of Natural and Applied Tracers to Guide Targeted Remediation Efforts in an Acid Mine Drainage System, Colorado Rockies, USA. Water 2014, 6, 745-777. [CrossRef]

12. Buzády, A.; Erostyák, J.; Paál, G. Determination of uranine tracer dye from underground water of Mecsek Hill, Hungary. J. Biochem. Biophys. Methods 2006, 69, 207-214. [CrossRef]

13. Magal, E.; Weisbrod, N.; Yakirevich, A.; Yechieli, Y. The use of fluorescent dyes as tracers in highly saline groundwater. J. Hydrol. 2008, 358, 124-133. [CrossRef]

14. Kania, M.; Matyasik, I. Testy stabilności znaczników fluorescencyjnych wykorzystywanych do śledzenia kierunku migracji płynów złożach gazu. Nafta-Gaz 2013, 4, 289-296.

15. Gutowski, L.; Olsson, O.; Lange, J.; Kümmerer, K. Photolytic transformation products and biological stability of the hydrological tracer Uranine. Sci. Total. Environ. 2015, 533, 446-453. [CrossRef]

16. Wojtowicz, K. Badanie stabilności barwnych znaczników fluorescencyjnych w silnie zasiarczonych wodach złożowych. Nafta-Gaz 2021, 2, 82-91. [CrossRef]

17. Kania, M.; Janiga, M. Elementy walidacji metody analitycznej oznaczania w mieszaninie gazowej związków węglowodorowych oraz $\mathrm{N}_{2}, \mathrm{O}_{2}, \mathrm{CO}$ i CO 2 za pomoca dwukanałowego, zaworowego chromatografu gazowego AGILENT 7890A. Nafta-Gaz 2011, 11, 812-824.

18. Uliasz-Misiak, B.; Chruszcz-Lipska, K. Aspekty hydrogeochemiczne związane z mieszaniem wód złożowych zatłaczanych do złoża węglowodorów. Gospod. Surowcami Miner. 2017, 33, 69-80. [CrossRef] 
19. Cascarano, R.N.; Reeves, D.M.; Henry, M.A. A Dye Tracer Approach for Quantifying Fluid and Solute Flux across the SedimentWater Interface. Groundwater 2021, 59, 428-437.

20. Silva, M. Development of New Oil/Water Partitioning Tracers for the Determination of Residual Oil Saturation in the Inter-Well Region of Water-Flooded Reservoirs. Ph.D. Thesis, University of Stavanger, Stravanger, Norway, 2021. ISBN 978-82-7644-994-5.

21. Bath, A. Drilling Fluid Tracers-Review and Update of Industry Experience and Issues for RWMD Site Characterysatin Programme. Radioactive Waste Management. 2011. Available online: https://rwm.nda.gov.uk/publication/drilling-fluid-tracersreview-and-update-of-industry-experience-and-issues-for-rwmd-site-characterisation-programme-april-2011/ (accessed on 28 September 2021).

22. Franke, C.; Westerholm, H.; Niessner, R. Solid-phase extraction (SPE) of the fluorescence tracers uranine and sulphorhodamine B. Water Res. 1997, 31, 2633-2637. [CrossRef]

23. Ikeya, T.; Horimoto, N.; Kashino, Y. A practical method for sensitive determination of the fluorescent water-tracer uranine by reversed phase HPLC under alkaline conditions. Talanta 2009, 79, 818-823. [CrossRef] [PubMed]

24. Weidner, C.; Naurath, L.; Rüde, T.R.; Banning, A. Parameters Affecting Nafluorescein (Uranine) Detection in Mine Water Tracer Tests, “Mine Water-Managing the Challenges" IMWA 2011. Available online: https://www.imwa.info/docs/imwa_2011 /IMWA2011_Weidner_327.pdf (accessed on 28 September 2021).

25. Li, Q.X.; Bender, C.J.V.; Alcantara-Licudine, J.P. Dissipation of Phloxine B and Uranine in Sediment and Water at a Kauai Spill Site. Bull. Environ. Contam. Toxicol. 1998, 61, 426-432. [CrossRef]

26. Li, Q.X.; Alcantara-Licudine, J.P.; Li, L.-P. Determination of phloxine B and uranine in water by capillary zone electrophoresis. J. Chromatogr. Sci. 1997, 35, 573-577. [CrossRef]

27. Namieśnik, J.; Konieczka, P.; Zygmunt, B.; Bulska, E.; Świtaj-Zawadka, A.; Ludwikowska, A.; Rompa, M.; Kremer, E. Ocena $i$ Kontrola Jakości Wyników Pomiarów Analitycznych; Wydawnictwo WNT: Warszawa, Poland, 2013.

28. Szczepaniak, W. Metody Instrumentalne w Analizie Chemicznej; Wydawnictwo Naukowe PWN: Warszawa, Poland, 2005.

29. Ferguson, J.; Etminan, H.; Ghassemi, F. Geochemistry of deep formation waters in the Canning Basin, Western Australia, and their relationship to Zn-Pb mineralization. Aust. J. Earth Sci. 1993, 40, 471-483. [CrossRef]

30. Arefieva, O.; Nazarkina, A.V.; Gruschakova, N.V.; Skurikhina, J.E.; Kolycheva, V.B. Impact of mine waters on chemical composition of soil in the Partizansk Coal Basin, Russia. Int. Soil Water Conserv. Res. 2019, 7, 57-63. [CrossRef]

31. Knapp, J.L.A.; González-Pinzón, R.; Drummond, J.D.; Larsen, L.G.; Cirpka, O.A.; Harvey, J.W. Tracer-based characterization of hyporheic exchange and benthic biolayers in streams. Water Resour. Res. 2017, 53, 1575-1594.

32. Matuszewska, A.; Czaja, M. The Use of Synchronous Fluorescence Technique in Environmental Investigations of Polycyclic Aromatic Hydrocarbons in Airborne Particulate Matter from an Industrial Region in Poland. 2020. Available online: https: / / www.intechopen.com/chapters/72246 (accessed on 28 September 2021). [CrossRef]

33. Kluk, D. Badania procesu mieszania wód zatłaczanych z wodami złożowymi o zróżnicowanych potencjałach elektrochemicznych. Nafta-Gaz 2011, 67, 98-106. 